\title{
NEONATAL RAT CARDIOMYOCYTES - A MODEL FOR THE STUDY OF MORPHOLOGICAL, BIOCHEMICAL AND ELECTROPHYSIOLOGICAL CHARACTERISTICS OF THE HEART
}

\author{
Šárka Chlopčíková, Jitka Psotová*, Petra Miketová
} Institute of Medical Chemistry and Biochemistry, Medical Faculty of Palacký University, 77515 Olomouc,
Czech Republic, psotova@tunw.upol.cz

Received: September 10, 2001

Key words: Rat cardiomyocytes/Cell culture/ Neonatal rat

Dedicated to the $60^{\text {th }}$ birthdays of prof. MUDr. Václav Lichnovský, DrSc.

The neonatal rat cardiomyocyte model enables heart researchers to study and understand the morphological, biochemical and electrophysiological characteristics of the heart. This model offers a broad spectrum of experiments, such as studies of contraction, ischaemia, hypoxia and the toxicity of various compounds. This review examines the methodology for the isolation and cultivation of primary neonatal rat cardiomyocyte cultures, considers possible problems and pitfalls, and presents an optimized protocol for cardiomyocyte preparation.

\section{INTRODUCTION}

The heart is one of the most essential organs for life. Researchers need to understand the mechanisms underlying normal cardiovascular function, to be able to design strategies to enhance cardioprotection and to ameliorate cardiovascular diseases. The most used experimental models in cardiac research are the isolated whole heart and cultured cardiac cells. Currently the use of cell cultures is taking on increasing relevance due to the versatility, economy and convenience of the methodology, as compared to whole animal experiments. In vitro models offer a broad spectrum of biochemical, physiological, pharmacological and morphological approaches ${ }^{1}$. Above all, animals experiments are conducted under specific conditions (temperature, diet, and a limited number of tested compounds), and practical and ethical limitations on animal numbers restrict the possibility of studying combined variables. In contrast, a single preparation of cells may be dispensed for multiple comparative in vitro studies. In particular, preparations of heart cells isolated from small mammals, rat $^{2-4}$, mouse ${ }^{5,6}$, hamster $^{7,8}$, chick $^{9-12}$, Guinea pig ${ }^{13,14}$, rabbit ${ }^{15,16}$ and feline ${ }^{17}$ allow a large number of experiments, which are conducted and evaluated quickly at relatively low cost. At present when many laboratories have to respect their budgets, the rat model appears one of the most advantageous for research. Rats are readily available, inexpensive, do not require the elaborate housing and care resources of larger animals and have an extensive scientific bibliography. Furthermore, experimental use of the rat has been exempted from many of the regulatory restrictions applied to larger mammals ${ }^{18}$.
The neonatal rat cardiomyocyte model permits the study of many of the morphological, biochemical and electrophysiological characteristics of the heart. This model is well-established for the study of the transport and toxicity of drugs ${ }^{2,19-21}$. Thanks to these experiments physicians now know how to estimate the optimum drug dose with minimum health risks to patients. Cardioprotective effects of promising therapeutic compounds were also studied using this model ${ }^{22,23}$.

Cultured neonatal rat cardiomyocytes have been shown to be useful for analyzing states of oxygen- and volume-restriction, conditions that are known to stimulate anoxia and ischaemia at the cellular level ${ }^{24,25}$. Musters et al. ${ }^{24}$ provided proof for the usefulness of this model for ischaemia in their study of morphological changes caused by volume-restricted anoxia. During ischaemia-reperfusion of the myocardium, reactive oxygen species (ROS) are generated and may contribute to the pathophysiology of cellular injury ${ }^{26}$. For this reason scientists study the mechanism of ROS-induced injury and possible ways of protection against ROS on neonatal rat cardiomyocytes ${ }^{23,27,28}$. Burton ${ }^{29}$ has shown that three specific lazaroids, U74006F, U75412E and U74500E, were able to attenuate oxidative damage and may represent potential therapeutic agents in the prevention of ROS-mediated myocardial damage.

Apoptosis is another pathological phenomenon that has been studied in cultured neonatal rat cardiomyocytes. Apoptosis occurs concomitantly with necrosis in the infarcted and reperfused myocardium, in the endstage failing heart, in postinfarction left ventricular remodeling, in diabetes and during the regression of hypertrophy ${ }^{30}$. Tanaka et al. ${ }^{31}$ demonstrated, with cultured 
cardiomyocytes under hypoxia, that cardiomyocytes die through apoptosis. The mechanism of apoptosis may involve the Fas antigen. Shimojo et al. $^{32}$ have produced evidence that nitric oxide induces the apoptotic death of cardiomyocytes via cGMP-dependent pathway. This model has been further exploited by Miletich et al. ${ }^{33}$, who used cultured neonatal rat cardiomyocytes as a tool for the evaluation of halothane-induced arrythmia. Other investigators have studied hypertrophy in neonatal cell cardiomyocytes $^{34,35}$. Experiments on cardiomyocytes facilitate the study of the myocardial cell morphology ${ }^{36-38}$, cellular ionic exchange ${ }^{39-41}$, metabolism ${ }^{42}$, contractile activities $^{43,44}$ and their mutual connections ${ }^{45-47}$. The expression of proteins ${ }^{48-50}$, regulation of their expression $^{51,52}$, and the effect of drugs on the expression ${ }^{53}$ were studied in the neonatal rat cardiomyocytes model.

The discussion below compares cultured neonatal rat heart cells with cardiomyocytes obtained from adult rat heart tissue.

\section{NEONATAL vs ADULT RAT CARDIOMYOCYTES}

Rat heart cells can be obtained from neonatal rats or adults. However, a typical rat litter of 10-20 neonatal pups furnishes sufficient tissue to be less expensive than an isolation from adult rats. A second advantage of neonatal cardiomyocytes is the undemanding and easy procedure for their isolation in contrast to adult cardiomyocytes, which are very sensitive to the concentration of $\mathrm{Ca}^{2+}$ in the medium (calcium paradox) (ref. ${ }^{54}$ ) during the whole isolation procedure. Yamashita et al. ${ }^{55}$ have noted that the phenotype of cultured neonatal cardiomyocytes is very stable and their contractile profile during hypoxia-reoxygenation is comparable with that of in situ hearts during ischemia-reperfusion, whereas the phenotype of isolated adult cardiomyocytes is quite different from that of in situ hearts.

\section{PREPARATION OF NEONATAL RAT CARDIOMYOCYTES}

Many protocols, describing isolation and cultivation of neonatal rat cardiomyocytes have been published in the past forty years. All are modifications of the method originally described by Harary and Farley in $1963^{43}$ and use the same rationale. Briefly, hearts from neonatal rats are rapidly excised and washed to remove blood and debris. Then whole hearts or only the ventricles are carefully minced and dissociated into single cells by proteolytic enzymes during repeated digestions with gentle stirring. The obtained cells are suspended in growth medium, which contains serum for deactivation of proteolytic enzymes. The cells are counted and adjusted to a desirable concentration. The cardiomyocytes are seeded on plastic plates and maintained in an incubator under defined atmosphere. Modifications on the method described by Harary and Farley are described below.

Animals. Sprague-Dawley ${ }^{39,44}$, Wistar ${ }^{4,51,56}$ and WisterKyoto rats ${ }^{48,57}$ can be used for isolation of neonatal cardiomyocytes. The isolation is the most successful when the rats are 1-5-days old. Cardiomyocytes will adhere to the cultivation plate, and initiate rhythmical contraction. Moreover these cardiomyocytes are more resistant to cellular disintegration than cardiomyocytes obtained from older rats, that also appear to be less active and lose contraction ability quickly. Quality of the cardiomyocyte preparation, as evidenced by an increase of cell debris and a loss of cell viability, decreases as the age of the neonatal rat increases ${ }^{3}$. Typically, newborn rats are sacrificed by decapitation ${ }^{2,36,58,59}$ although head concussion ${ }^{44}$ and ether anaesthesia ${ }^{48}$ are also used.

Enzyme digestion. Two enzymes, trypsin ${ }^{4,36,60}$ and collagenase ${ }^{31,48,51,52,61,62}$, are generally used to dissociate cut pieces of heart tissue $\left(1-2 \mathrm{~mm}^{3}\right)$ into single cells. The concentration of trypsin, the most commonly employed enzyme, ranges from $0.05-0.25 \%$. Collagenase is used at lower concentrations, typically $0.05-0.1 \%$. Some protocols call for the use of a combination of the proteolytic enzymes, such as trypsin and collagenase ${ }^{2,53}$ or collagenase and pancreatin ${ }^{25,49,51}$.

After incubation of the minced heart with enzymecontaining solution the free cell-enriched solution is mixed with serum to stop enzyme proteolytic activity and centrifuged. The sediment of cells is resuspended in serum and cell suspensions from the digestions are kept in an incubator with a defined atmosphere. The pieces of tissue are incubated again with a fresh solution-containing enzyme.

Mark et al. ${ }^{56}$ reported that trypsinization, if repeated for short periods of incubation, gives a higher proportion of undamaged muscle cells than does a single digestion for a longer time. Five to eight incubations with trypsin (10-20 min each) appears to be most suitable treatment for isolation of cardiac cells that retain their original properties. Removal of the cell suspension after the first ${ }^{4,56}$ or the first three ${ }^{36,58}$ enzyme exposures, which removes dead and damaged cells, debris, and blood cells, also contributes to the higher yield of viable cardiac cells and the quality of the primary culture. Orita et al. ${ }^{22}$ published a preparation of cardiac cells, in which he used only one enzyme digestion $(60 \mathrm{~min})$ to isolate cardiac cells. This method is not much used.

Incubation of minced heart with enzyme solution is usually carried out at $37{ }^{\circ} \mathrm{C}$ (ref. ${ }^{36,41,44,60}$ ). However, some authors digest at $30{ }^{\circ} \mathrm{C}$ (ref. $\left.{ }^{4}\right), 36{ }^{\circ} \mathrm{C}$ (ref. ${ }^{42}$ ) and $24^{\circ} \mathrm{C}$ (ref. $\left.{ }^{63}\right)$. The effect of temperature on the isolation of neonatal cardiomyocytes has not been evaluated yet, to our knowledge.

Medium. During isolation and cultivation of rat neonatal cardiomyocytes three kinds of solutions (i) Wash solution, (ii) Enzyme solution, (iii) Growth (culture, plating) medium are employed. 
Hank's balanced salt solution $\left(\mathrm{Ca}^{2+}\right.$ and $\mathrm{Mg}^{2+}$-free $)$ (ref., ${ }^{24}$ ), phosphate-buffered saline (PBS) with $\mathrm{Ca}^{2+} 48$ or $\mathrm{Ca}^{2+}$ and $\mathrm{Mg}^{2+}-\mathrm{free}^{60}$, saline solutions ${ }^{24,36,38,58,63}$, Tyrode balanced salt solution $\left(\mathrm{Ca}^{2+}\right.$ and $\mathrm{Mg}^{2+}$-free $)\left(\right.$ ref..$\left.^{56}\right)$, HEPES-buffered salt solution $\left(\mathrm{Ca}^{2+}\right.$ free) $\left(\right.$ ref. $\left.^{45}\right)$, Eagle's MEM with Earle's balanced salt solution ${ }^{21,33,63}$ have been used as wash solutions. The wash solution rinses erythrocytes and tissue debris away from the minced tissue in the first step of the isolation procedure.

The wash solutions are the basis for the enzyme solutions, to which specific proteolytic enzymes have been added for dissociation of cardiac tissue into single cells. Some authors add antibiotics ${ }^{36,38,58,63}$, serum $(10 \%)$ (ref. $\left.{ }^{21}\right)$, glucose ${ }^{2}$ and Dnase $(0.002 \%)$ (ref. ${ }^{63}$ ) to these solutions, as well. A cell pellet is obtained and suspended in growth medium, in which cells are also subsequently cultured. This may be consist of individual medium Ham F10 (ref. ${ }^{24}, 27,36,58$ ), Ham's-F12 (ref. ${ }^{2}$ ), Dulbecco's modified Eagle's medium (DMEM) (ref..$\left.^{4}\right)$, Minimum Essential medium (MEM) (ref. ${ }^{42,44,60}$ ), M199 (ref. $^{41}$ ), MCDB 107 (ref. $^{64}$ ), Liebowitz's M3 medium ${ }^{65,66}$, PC-1 tissue culture medium ${ }^{50,52}$ or the combination of mediums DMEM and Ham's F-12 (ref. ${ }^{51,53}$ ), DMEM and M199 (ref. ${ }^{37,45,52}$ ), Hank's salts and M199 (ref. ${ }^{63}$ ).

The growth medium contains 4-20\% of serum, which is the essential part of the growth medium. We have found the following serums reported in the literature: horse serum (HS) (ref. ${ }^{53,61}$ ), fetal calf serum (FCS) $\left(\right.$ ref. $\left.^{49}\right)$, new-born calf serum ${ }^{51}$, calf serum ${ }^{44,60}$. The mixtures of HS with FCS (ref. ${ }^{2,24,37,39,45}$ ) are the most popular.

We notice some authors have used medium or maintenance medium that can differ from growth medium in the percentage of serum ${ }^{37,51}$ or composition ${ }^{2,67}$. Growth medium is replaced by maintenance medium during the first day or after 1-2 days ${ }^{2,37,51}$. The growth or maintenance medium is renewed every day ${ }^{23,50}$ or every two days $^{68}$. Experiments are usually performed after 3-8 days in culture $2,37,66$.

Antibiotics, which protect cultured cardiomyocytes from contamination (gram-negative and gram-positive bacteria), are the next important components of growth medium. The combination of penicillin (100-400 U/ml medium) and streptomycin (100-200 $\mu \mathrm{g} / \mathrm{ml}$ medium) is frequently used.

Elimination of non-muscle cells. Cells isolated from neonatal rat heart contain a mixture of muscle and mesenchymal cells. Mesenchymal cells divide more rapidly than the muscle cells and pervade all the free substrate surface, but do not overgrow the cardiomyocytes $^{56,60}$. The elimination of non-muscle cells is based on the different characteristics of muscle and non-muscle cells, such as speed of attachment to the plate surface, density of cells and proliferation rate. Blondel at al. ${ }^{60}$ have published a simple method for increasing the proportion of muscle cells based on the faster rate of attachment to the plate surface of mesenchymal cells, as compared to muscle cells. This tech- nique of the pre-plating step, when the cell suspension is plated in a flask for 1-3 hours for attachment of nonmuscle cells, is the most popular method for elimination of non-muscle cells ${ }^{2}, 39,48,51$. Cell cultures prepared with this technique contain about 97-99\% of cardiomyocytes $^{49}$. The following methods are based on reducing the growth of non-muscle cells by inhibitors of proliferation, such as cytosine- $\beta$-D-arabinofuranoside (10 $\mu \mathrm{g} / \mathrm{mL}$ medium) (ref. ${ }^{31,38,62}$ ) and 5-bromo-2'-deoxyuridine $(100 \mu \mathrm{M})\left(\right.$ ref. $\left.^{48,51,53}\right)$. Mediums supplemented with these compounds have been used for seeding and maintenance of cardiomyocytes. Cell cultures that grow without these proliferation inhibitors showed 40-65\% increase in the number of fibroblasts from day 1 to day 5 $\left(\right.$ ref. $^{62}$ ). The method Percoll gradient ${ }^{45,46,69}$ is the third technique for separation of mixed cell population. Since this technique is more complicated and takes more time, it is not very popular. The cell suspension is layered onto a Percoll density gradient (density, 1.059/1.082) and centrifuged at low speed. The cell fraction migrating at density layers of 1.062 and 1.082 on a Percoll gradient is enriched for cardiomyocytes. This fraction is removed carefully and washed in medium or wash solution. Using this technique the cells reach confluence after approximately 72 hours $^{25}$. The percentage of beating cardiomyocytes exceeds $95 \%$ after 3 days in culture, because the Percoll separation removes about $91 \%$ of the fibroblasts with only a $26 \%$ loss of myocytes ${ }^{62}$. Some authors use combination of these methods to increase percentage of beating cardiomyocytes ${ }^{24,62,63}$.

Seeding. After counting cells, the cell suspension is adjusted to a concentration range of $1 \times 10^{4}-2.5 \times 10^{5}$ cell $/ \mathrm{cm}^{2}$. Cells can be plated on disks pretreated with collagen (Types ${ }^{62,69}$ and III $^{69}$ ), fibronectin ${ }^{37,64}$, lami$\operatorname{nin}^{45,69}$, gelatin ${ }^{70}$ or on Primaria (Falcon Plastics) ${ }^{24,36,58}$ - and pronectin (Promega) ${ }^{53}$-coated culture plates. Within the first day the cells attach to the surface of the flask and spread out. A confluent monolayer of spontaneously beating pure myocytes forms within 2-3 days. Vanwinkle et al. ${ }^{69}$ have published a very interesting procedure for cultivation of rat cardiomyocytes on a naturally occurring complete extracellular matrix, cardiogel, which is synthesized by cardiac fibroblasts. It contains laminin, fibronectin, Type I and III collagen, and proteoglycans, that contribute extensively to the interstitial extracellular matrix in the heart. Cardiogel-supported cardiomyocytes adhere more rapidly after plating, exhibit spontaneous contractility earlier, undergo cytoskeletal and myofibrillar differentiation earlier and grow larger than their counterparts ${ }^{69}$. The same cardiogel feature was noticed by Bick ${ }^{46}$, who published a study comparing the properties of laminin and fibronectin with cardiogel. Laminin appeared to be the least suitable matrix for the culture of neonatal cardiac myocytes, but has been widely used ${ }^{46}$. Although cardiogel is the most suitable matrix, its time arduousness limits its current use. 
Incubation atmosphere. At the end of isolation, cardiomyocytes plated in tissue culture dishes are usually cultured at $37{ }^{\circ} \mathrm{C}$ under an atmosphere of $\mathrm{CO}_{2}(1-10 \%)$ and air or $\mathrm{O}_{2}(90-99 \%)$ (ref., 3, 38, 48, 53). Courtois ${ }^{27}$, who incubated cardiomyocytes at $37{ }^{\circ} \mathrm{C}$ in a humidified atmosphere containing $5 \% \mathrm{CO}_{2}, 19 \% \mathrm{O}_{2}$ and $76 \% \mathrm{~N}_{2}$, is an exception.

\section{OPTIMIZED PREPARATION OF NEONATAL RAT CARDIOMYOCYTES}

We describe below a standard protocol for the isolation and maintenance of cardiomyocytes obtained from neonatal rat heart that conveniently, routinely and repeatedly yields high quality cardiomyocyte cultures in our laboratory.

Whole hearts are isolated from 2- to 5-day old rats and minced in a balanced salt solution containing $20 \mathrm{mM}$ HEPES, $120 \mathrm{mM} \mathrm{NaCl}, 1 \mathrm{mM} \mathrm{NaH} \mathrm{PO}_{4}, 5.5 \mathrm{mM}$ glucose, $5.4 \mathrm{mM} \mathrm{KCl}, 0.8 \mathrm{mM} \mathrm{MgSO}_{4}$ (pH 7.3-7.4). The myocardial cells are dispersed by the addition of a balanced salt solution containing trypsin $(0.2 \%)$ and then stirred at $37^{\circ} \mathrm{C}$ in a water bath for $20 \mathrm{~min}$. The enzymatic solution with free cells is removed and discarded. The pieces of tissue are incubated again with fresh solution containing trypsin $(0.2 \%)$ for $20 \mathrm{~min}$ at $37{ }^{\circ} \mathrm{C}$. The supernatant is collected and centrifuged at $1200 \mathrm{rpm}$ for $10 \mathrm{~min}$. The obtained pellet of cells is resuspended in $2 \mathrm{ml}$ newborn calf serum. The cell suspension is kept at $37{ }^{\circ} \mathrm{C}$ in an incubator under an atmosphere of $95 \%$ air and $5 \% \mathrm{CO}_{2}$. The digestion step is repeated five times. The cell suspensions from each digestion are combined and centrifuged at $1200 \mathrm{rpm}$ for $10 \mathrm{~min}$. The pellet of cells is resuspended in medium containing DMEM and M199 (4:1) supplemented with horse serum (10\%), fetal calf serum $(5 \%)$, penicillin $(100 \mathrm{U} / \mathrm{ml})$ and streptomycin $(100 \mathrm{mg} / \mathrm{ml})$. The cells are plated for $1.5-2 \mathrm{~h}$ to allow the differential attachment of non-myocardial cells. The non-adhesive cells (cardiomyocytes) are transferred into a centrifugation tube, washed and centrifuged at $1200 \mathrm{rpm}$ for $10 \mathrm{~min}$. After counting the myocyte-enriched suspension is transferred to collagen I-coated culture dishes at density of $5 \times 10^{4}$ cells per $\mathrm{cm}^{2}$. The viability of cells $(85-90 \%)$ is determined by exclusion of trypan blue dye. The cells are incubated in $95 \%$ air and 5\% $\mathrm{CO}_{2}$ at $37^{\circ} \mathrm{C}$. The medium is removed after $72 \mathrm{~h}$ and replaced by a medium containing DMEM and M199 (4:1) with penicillin $(100 \mathrm{U} / \mathrm{ml})$ and streptomycin $(100 \mathrm{mg} / \mathrm{ml})$. The cultured cardiomyocytes are allowed to reach confluence before being used experimentally. Using this technique the percentage of beating myocardial cells exceeds $85 \%$ after $3 \mathrm{~d}$ in culture in each experiment. Fig. 1 shows the development of cardiomyocytes cultures during 3 days and the toxic effect of anthracycline antibiotic, doxorubicin, on a 3-day-old culture.

\section{ACKNOWLEDGEMENTS}

This work was supported by The Ministry of Education, Youth and Sports of The Czech Republic (MSM:151100003). We thank Professor M. Brabec, Easter Michigan University, for his review of preliminary manuscript.

\section{REFERENCES}

1. Sutherland, F. J., Hearse, D. J. (2000) The isolated blood and perfusion fluid perfused heart. Pharmacol. Res. 41, 613-627.

2. Estevez, M. D., Wolf, A., Schramm, U. (2000) Effect of PSC 833, Verapamil and Amiodarone on adriamycin toxicity in cultured rat cardiomyocytes. Toxicol. in Vitro 14, 17-23.

3. Harary, I., Farley, B. (1963) In vitro studies on single beating rat heart cells. Exp. Cell. Res. 29, 451-465.

4. Grynberg, A., Athias, P., Degois, M. (1986) Effect of change in growth environment on cultured myocardial cells investigated in a standardized medium. In Vitro Cell. Dev. Biol. 22, 44-50.

5. Wang, G., Schuschke, D. A., Kang, Y. J. (1999) Metallothioneinoverexpressing neonatal mouse cardiomyocytes are resistant to $\mathrm{H}_{2} \mathrm{O}_{2}$. Am. J. Physiol. 276, H167-H175.

6. Goshima, K., Tonomura, Y. (1969) Synchronized beating of embryonic mouse myocardial cells mediated by FL cells in monolayer culture. Exp. Cell Res. 56, 387-392.

7. Ray, M., Roy, R., Chowdhury, P. D., Srivastava, S., Dubey, M. P. (2000) The hamster Heart: a paradox in itself. Pharmacol. Res. 41, 361-367.

8. Doliba, Nic. M., Doliba, Nat. M., Chang, Q., Babsky, A. M., Wroblewski, K., Natelson, B. H., Osbakken, M. D. (1999) Mitochondrial oxidative phosphorylation in heart from stressed cardiomyopathic hamsters. J. Mol. Cell Cardiol. 31, 543-553.

9. Boyle, R. T., Lieberman, M. (1999) Permeabilization by streptolysin-O reveals a role for calcium-dependent protein kinase $\mathrm{C}$ isoforms alpha and beta in the response of cultured cardiomyocytes to hyposmotic challenge. Cell Biol. Int. 23, 685-693.

10. Murphy, E., Aiton, J. F., Horres, C. R., Lieberman, M. (1983) Calcium elevation in cultured heart cells: its role in cell injury. Am. J. Physiol. 245, C316-C321.

11. Clark, Jr., W. A. (1976) Selective control of fibroblast proliferation and its effect on cardiac muscle differentiation in vitro. Develop. Biol. 52, 263-282.

12. Bkaily, G., Sperelakis, N., Elishalom, Y., Barenholz, Y. (1983) Effect of $\mathrm{Na}^{+}-$or $\mathrm{Ca}^{2+}$-filled liposomes on electrical activity of cultured heart cells. Am. J. Physiol. 245, H756-H761.

13. Jovanovic, A., Lopez, J. R., Terzic, A. (1996) Cytosolic $\mathrm{Ca}^{2+}$ domain-dependent protective action of adenosine in cardiomyocytes. Eur. J. Pharmacol. 298, 63-69.

14. Severs, N. J., Twist, V. W., Powel, T. (1991) Acute effects of adriamycin on the macromolecular organization of the cardiac muscle cell plasma membrane. Cardioscience 2, 35-45.

15. Shadle, S. E., Bammel, B. P., Cusack, B. J., Knighton, R. A., Olson, S. J., Mushlin, P. S., Olson, R. D. (2000) Daunorubicin cardiotoxicity. Biochem. Pharmacol. 60, 1435-1444.

16. Wetzel, G. T., Chen, F., Klitzner, T. S. (1995) $\mathrm{Na}^{+} / \mathrm{Ca}^{2+}$ exchange and cell contraction in isolated neonatal and adult rabbit cardiac myocytes. Am. J. Physiol. 268, H1723-H1733.

17. Simpson, D. G., Decker, M. L., Clark, W. A., Decker, R. S. (1993) Contractile activity and cell-cell contact regulate myofibrillar organization in cultured cardiac myocytes. J. Cell Biol. 123, 323-336.

18. Muders, F., Elsner, D. (2000) Animal models of chronic heart failure. Pharmacol. Res. 41, 605-612.

19. Limaye, D. A., Shaikh, Z. A. (1999) Cytotoxicity of cadmium and characteristics of its transport in cardiomyocytes. Toxicol. Appl. Pharmacol. 154, 59-66. 
20. Acosta, D., Ramos, K. (1984) Cardiotoxicity of tricyclic antidepressants in primary cultures of rat myocardial cells. J. Toxicol. Environ. Health 14, 137-143.

21. Wenzel, D. G., Wheatley, J. W., Don Byrd, G. (1970) Effects of nicotine on cultured rat heart cells. Toxicol. Appl. Pharmacol. 17, 774-785.

22. Orita, H., Fukasawa, M., Hirooka, S., Uchino, H., Fukui, K., Kohi, M., Washio, M. (1994) Cytoprotective effects of nicorandil on hypothermic injury to immature cardiac myocytes. Jpn. Circ. J. 58, 653-661.

23. Ek, B., Hallberg, C., Sjogren, K.-G., Hjalmarson, A. (1994) Reoxygenation-induced cell damage of isolated neonatal rat ventricular myocytes can be reduced by chain-breaking antioxidants. Free Radical Biol. Med. 16, 117-121.

24. Musters, R. J. Ph., Post, J. A., Verkleij, A. J. (1991) The isolated neonatal rat-cardiomyocyte used in an in vitro model for 'ischemia'. I. A morphological study. Biochim. Biophys. Acta 1091, 270-277.

25. Iwaki, K., Chi, S.-H., Dillmann, W. H., Mestril, R. (1993) Induction of HSP70 in cultured rat neonatal cardiomyocytes by hypoxia and metabolic stress. Circ. Res. 87, 2023-2032.

26. Steare, S. E., Yellon, D. M. (1995) The potential for endogenous myocardial antioxidants to protect the myocardium against ischaemia-reperfusion injury: refreshing the parts exogenous antioxidants cannot reach? J. Mol. Cell Cardiol. 27, 65-74.

27. Courtois, M., Maupoil, V., Fantini, E., Durot, I., Javouhey-Donzel, A., Athias, P., Grynberg, A., Rochette, L. (1998) Correlation between direct ESR spectroscopic measurements and electromechanical and biochemical assessments of exogenous free radical injury in isolated rat cardiac myocytes. Free Radical Biol. Med. 24, 121-131.

28. Durot, I., Maupoil, V., Ponsard, B., Cordelet, C., Vergely-Vandriesse, C., Rochette, L., Athias, P. (2000) Oxidative injury of isolated cardiomyocytes: dependence on free radical species. Free Radic. Biol. Med. 29, 846-857.

29. Burton, K. P. (1994) Effects of 21-aminosteroids in neonatal rat cardiac myocyte cell cultures exposed to free radicals. Cardiovasc. Res. 28, 1500-1506.

30. Bishopric, N. H., Andreka, P., Slepak, T., Webster, K. A. (2001) Molecular mechanisms of apoptosis in the cardiac myocyte. Current Opinion in Pharmacology 1, 141-150.

31. Tanaka, M., Ito, H., Adachi, S., Akimoto, H., Nishikawa, T. Kasajima, T., Marumo, F., Hiroe, M. (1994) Hypoxia induces apoptosis with enhanced expression of Fas antigen messenger RNA in cultured neonatal rat cardiomyocytes. Circ. Res. 75, 426-433.

32. Shimojo, T., Hiroe, M., Ishiyama, S., Ito, H., Nishikawa, T., Marumo, F. (1999) Nitric oxide induces apoptotic death of cardiomyocytes via a cyclic-GMP-dependent pathway. Exp. Cell Res. 247, 38-47.

33. Miletich, D. J., Khan, A., Albrecht, R. F., Jozefiak, A. (1983) Use of heart cell cultures as a tool for the evaluation of halothane arrhytmia. Toxicol. Appl. Pharmacol. 70, 181-187.

34. Gray, M. O., Long, C. S., Kalinyak, J. E., Li, H.-T., Karliner, J. S. (1998) Angiotensin II stimulates cardiac myocyte hypertrophy via paracrine release of TGF- $\beta_{1}$ and endothelin- 1 from fibroblasts. Cardiovasc. Res. 40, 352-363.

35. Kaburagi, S., Hasegawa, K., Morimoto, T., Araki, M., Sawamura, T., Masaki, T., Sasayama, S. (1999) The role of endothelin-converting enzyme- 1 in the development of $\alpha_{1}$-adrenergic-stimulated hypertrophy in cultured neonatal rat cardiac myocytes. Circulation 99, 292-298.

36. Post, J. A., Langer, G. A., Op den Kamp, J. A. F., Verkleij, A. J. (1988) Phospholipid asymmetry in cardiac sarcolemma. Anylysis of intact cells and "gas-dissected" membranes. Biochim. Biophys. Acta 943, 256-266.

37. Rothen-Rutishauser, B. M., Ehler, E., Perriard, E., Messerli, J. M., Perriard, J.-C. (1998) Different behaviour of the non-sarcomeric cytoskeleton in neonatal and adult rat cardiomyocytes. J. Mol. Cell. Cardiol. 30, 19-31.

38. Matos, M. J., Post, J. A., Roelofsen, B., Op den Kamp, J. A. F. (1990) Composition and organization of sarcolemmal fatty acids in cultured neonatal rat cardiomyocytes. Cell. Biol. Int. Rep. 14, 343-352.
39. Marengo, F. D., Wang, S., Wang, B., Langer, G. A. (1998) Dependence of cardiac cell $\mathrm{Ca}^{2+}$ permeability on sialic acid-containing sarcolemmal gangliosides. J. Mol. Cell Cardiol. 30, 127-137.

40. Hoffmann, P., Richards, D., Heinroth-Hoffmann, I., Mathias, P., Wey, H., Toraason, M. (1995) Arachidonic acid disrupts calcium dynamics in neonatal rat cardiac myocytes. Cardiovasc. Res. 30, 889-898.

41. Ichiba, T., Matsuda, N., Takemoto, N., Ishiguro, S., Kuroda, H., Mori, T. (1998) Regulation of intracellular calcium concentrations by calcium and magnesium in cardioplegic solutions protects rat neonatal myocytes from simulated ischemia. J. Mol. Cell Cardiol. 30, 1105-1114.

42. Ross, P. D., McCarl, R. L. (1984) Oxidation of carbohydrates and palmitate by intact cultured neonatal rat heart cells. Am. J. Physiol. 246, H389-H397.

43. Harary, I., Farley, B. (1963) In vitro studies on single beating rat heart cells. Exp. Cell Res. 29, 466-474.

44. Galaris, D., Höijer, B., Rydström, J. (1980) Improved methods for automatic monitoring of contracting heart cells in culture. $\mathrm{J}$. Biochem. Biophys. Methods 2, 213-225.

45. Burton, K. P., Morris, A. C., Massey, K. D., Buja, L. M., Hagler, H. K. (1990) Free radicals alter ionic calcium levels and membrane phospholipids in cultured rat ventricular myocytes. J. Mol. Cell Cardiol. 22, 1035-1047.

46. Bick, R. J., Snuggs, M. B., Poindexter, B. J., Buja, L. M., Van Winkle, W. B. (1998) Physical, contractile and calcium handling properties of neonatal cardiac myocytes cultured on different matrices. Cell Adhes. Commun. 6, 301-310.

47. Frank, J. S., Langer, G. A., Nudd, L. M., Seraydarian, K. (1977) The myocardial cell surface, its histochemistry, and the effect of sialic acid and calcium removal on its structure and cellular ionic exchange. Circ. Res. 41, 702-714.

48. Hoshida, S., Nishida, M., Yamashita, N., Igarashi, J., Aoki, K., Hori, M., Kuzuya T., Tada, M. (1996) Heme oxygenese-1 expression and its relation to oxidative stress during primary culture of cardiomyocytes. J. Mol. Cell Cardiol. 28, 1845-1855.

49. Brooks, G., Poolman, R. A., McGill, C. J., Li, J.-M. (1997) Expression and activities of cyclins and cyclin-dependent kinases in developing rat ventricular myocytes. J. Mol. Cell Cardiol. 29, 2261-2271.

50. Eble, D. M., Cadre, B. M., Qi, M., Bers, D. M., Samarel, A. M. (1998) Contractile activity modulates atrial natriuretic factor gene expression in neonatal rat ventricular myocytes. J. Mol. Cell Cardiol. 30, 55-60.

51. Adderley, S. R., Fitzgerald, D. J. (1999) Oxidative damage of cardiomyocytes is limited by extracellular regulated kinases 1/2-mediated induction of cyclooxygenase-2. J. Biol. Chem. 274, 5038-5046.

52. Cadre, B. M., Qi, M., Eble, D. M., Shannon, T. R., Bers, D. M., Samarel, A. M. (1998) Cyclic stretch down-regulates calcium transporter gene expression in neonatal rat ventricular myocytes. J. Mol. Cell Cardiol. 30, 2247-2259.

53. Wagner, D. R., Combes, A., McTiernan, Ch., Sanders, V. J., Lemster, B., Feldman, A. M. (1998) Adenosine inhibits lipopolysaccharide-induced cardiac expression of tumor necrosis factor- $\alpha$. Circ. Res. 82, 47-56.

54. Ray, M., Srivastava, S., Maitra, S. Ch., Dubey, M. P. (2000) The hamster heart is resistant to calcium paradox. Pharmacol. Res. 41, 475-481.

55. Yamashita, N., Nishida, M., Hoshida, S., Kuzuya, T., Hori, M., Taniguchi, N., Kamada, T., Tada, M. (1994) Induction of manganese superoxide dismutase in rat cardiac myocytes increases tolerance to hypoxia 24 hours after preconditioning. J. Clin. Invest. 94, 2193-2199.

56. Mark, G. E., Strasser, F. F. (1966) Pacemaker activity and mitosis in cultures of newborn rat heart ventricle cells. Exp. Cell Res. 44 217-233.

57. Maeda, A., Honda, M., Kuramochi, T., Takabatake, T. (1999) A calcium antagonist protects against doxorubicin-induced impairment of calcium handling in neonatal rat cardiac myocytes. Jpn. Circ. J. 63, 123-129.

58. Post, J. A., Langer, G. A. (1992) Sarcolemmal calcium binding sites in heart: I. Molecular origin in "gas-dissected" sarcolemma. J. Membrane Biol. 129, 49-57. 
59. Lampidis, T. J., Henderson, I. C., Israel, M., Canellos, G. P. (1980) Structural and functional effects of adriamycin on cardiac cells in vitro. Cancer Res. 40, 3901-3909.

60. Blondel, B., Roijem, I., Cheneval, J. P. (1971) Heart cells in culture: a simple method for increasing the proportion of myoblasts. Experientia 27, 356-358.

61. Demant, E. J. F., Wassermann, K. (1985) Doxorubicin induced alterations in lipid metabolism of cultured myocardial cells. Biochem. Pharmacol. 34, 1741-1746.

62. Ollinger, K., Brunmark, A. (1994) Effect of different oxygen pressures and $\mathrm{N}, \mathrm{N}$-diphenyl-p-phenylenediamine on adriamycin $^{\circledR}$ toxicity to cultured neonatal rat heart myocytes. Biochem. Pharmacol. 48, 1707-1715.

63. Simpson, P., Savion, S. (1982) Differentiation of rat myocytes in single cell cultures with and without proliferating nonmyocardial cells. Circ. Res. 50, 101-116.

64. Suzuki, T., Tsuruda, A., Katoh, S., Kubodera, A., Mitsui, Y. (1997) Purification of endothelin from a conditioned medium of cardiac fibroblastic cells using beating rate assay of myocytes cultured in a serum-free medium. J. Mol. Cell Cardiol. 29, 2087-2093.
65. Paranka, N. S., Dorr, R. T. (1994) Effect of doxorubicin on glutathione and glutathione-dependent enzymes in cultured rat heart cells. Anticancer Res. 14, 2047-2052.

66. Dorr, R. T., Lagel, K. (1994) Effect of sulfhydryl compounds and glutathione depletion on rat heart myocyte toxicity induced by 4-hydroperoxycyclophosphamide and acrolein in vitro. Chem. - Biol. Interact. 93, 117-128.

67. Li, Y.-P., Schwartz, R. J., Waddell, I. D., Holloway, B. R., Reid, M. B. (1998) Skeletal muscle myocytes undergo protein loss and reactive oxygen-mediated NF- $\mathrm{\kappa B}$ activation in response to tumor necrosis factor $\alpha$. FASEB J. 12, 871-880.

68. Shirhatti, V., Krishna, G. (1985) A simple and sensitive method for monitoring drug-induced cell injury in cultured cells. Anal. Biochem. 147, 410-418.

69. Vanwinkle, W. B., Snuggs, M. B., Buja, L. M. (1996) Cardiogel: a biosynthetic extracellular matrix for cardiomyocyte culture. In Vitro Cell. Dev. Biol. 32, 478-485.

70. Schaffer, S. W., Ballard-Croft, C., Azuma, J., Takahashi, K., Kakhniashvili, D. G., Jenkins, T. E. (1998) Amino Acids 15, 135-142. 

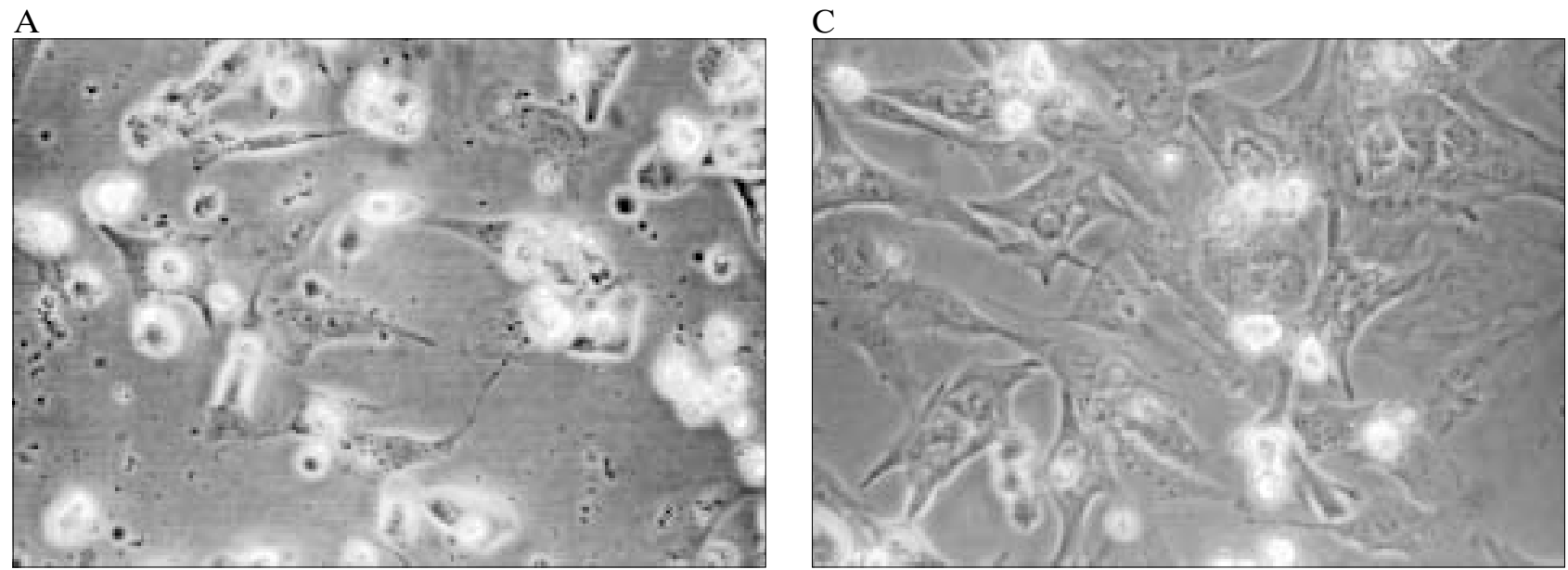

$\mathrm{B}$

$\mathrm{D}$
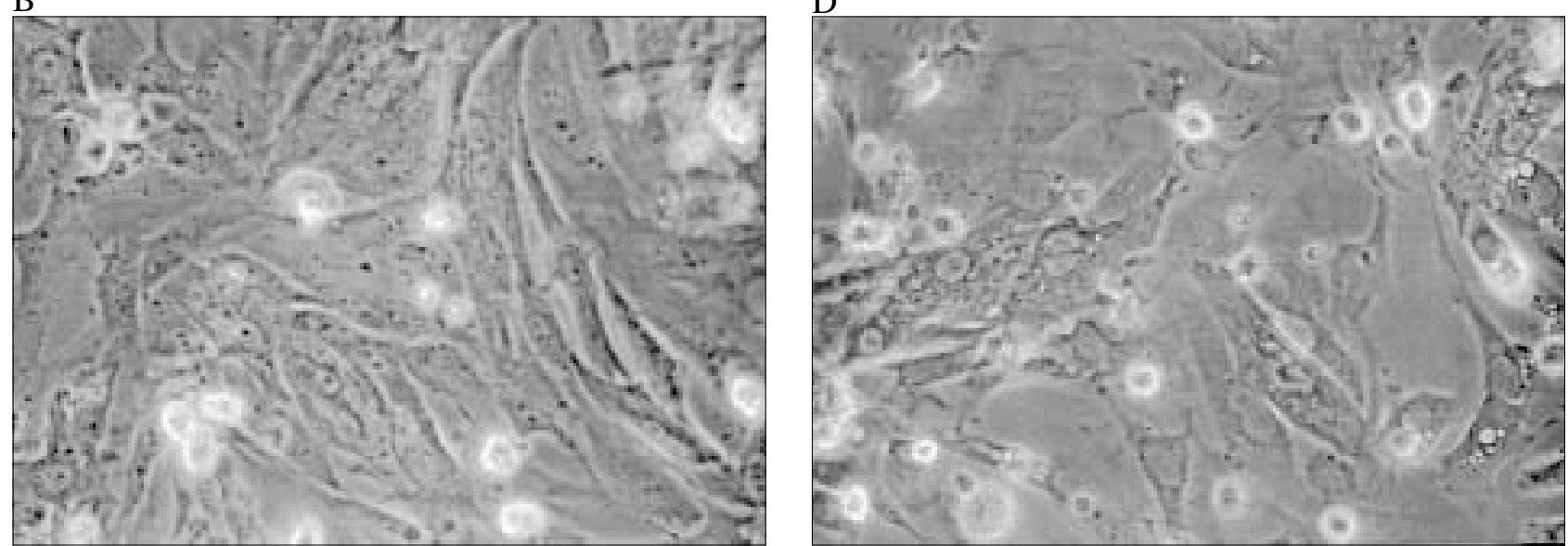

Fig. 1. Selected microphotographs of the developmental stages of cultured neonatal rat cardiac myocytes and toxic effect of doxorubicin (400×). Cells were isolated from 3-day-old neonatal rats and cultured on collagen-coated multiwell plate dishes in growth medium, see text. Panels A, B, and C represent cardiomyocytes incubated for $24 \mathrm{~h} ; 48 \mathrm{~h}$ and $72 \mathrm{~h}$, respectively. These cells (panel C) were beating spontaneously and synchronic at $145-170$ beats/min. Panel C is simultaneously a control for panel D. Panel D represents myocytes incubated with $100 \mu \mathrm{M}$ doxorubicin for $8 \mathrm{~h}$, myocytes were arrhythmically beating 70-90 beats/min. The cell monolayer was not continued and the small vacuoles were found in cardiomyocytes cytoplasm. 